\title{
Hydrocarboniphaga daqingensis sp. nov., isolated from a freshwater lake
}

\author{
Correspondence \\ Zhi-Pei Liu \\ liuzhp@sun.im.ac.cn
}

\author{
Ying Liu, ${ }^{1}$ Xue-Feng Song, ${ }^{2}$ Jia-Tong Jiang, ${ }^{1}$ Ying-Hao Liu, ${ }^{1}$ \\ Cheng-Jun $\mathrm{Xu}^{2}{ }^{2} \mathrm{HaO} \mathrm{Li}^{2}$ and Zhi-Pei Liu ${ }^{1}$ \\ ${ }^{1}$ State Key Laboratory of Microbial Resources, Institute of Microbiology, Chinese Academy of \\ Sciences, Beijing 100101, PR China \\ ${ }^{2}$ Water Supply Company of Daqing Petroleum Administration, No. 49, Aiguo Road, Ranghulu \\ District, Daqing 163453, PR China
}

The genus Hydrocarboniphaga of the class Gammaproteobacteria was proposed by Palleroni et al. (2004) to accommodate aerobic, heterotrophic, Gram-negative bacteria that can grow on aliphatic hydrocarbons. At the time of writing, the genus Hydrocarboniphaga comprises one species with a validly published name, Hydrocarboniphaga effusa (Palleroni et al., 2004), which was characterized by growing on n-alkanes. The phenotypic characteristics of $H$. effusa include good growth with complex and chemically defined media without organic growth factors and the formation of diffuse colonies on minimal agar.

In this study, we report the isolation and taxonomic characterization of an alkane-utilizing bacterium, strain B2 $-9^{\mathrm{T}}$, which was isolated from surface water of a slightly alkaline lake, Longhu Lake in Daqing, north-east China

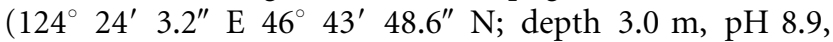
$23{ }^{\circ} \mathrm{C}$, chemical oxygen demand $25 \mathrm{mg} \mathrm{l}^{-1}$, biological oxygen demand $15 \mathrm{mg} \mathrm{l}^{-1}$, total nitrogen $1.1 \mathrm{mg} \mathrm{l}^{-1}$, total phosphorus $0.10 \mathrm{mg} \mathrm{l}^{-1}$ ). For isolation, serially diluted

The GenBank/EMBL/DDBJ accession number for the 16S rRNA gene sequence of strain $B 2-9^{\top}$ is EU313812.

A supplementary figure and a supplementary table are available with the online version of this paper. water was spread onto low-organic Luria-Bertani agar [containing $\mathrm{l}^{-1}: 1.0 \mathrm{~g}$ tryptone (Difco), $0.5 \mathrm{~g}$ yeast extract and $10.0 \mathrm{~g} \mathrm{NaCl} ; \mathrm{pH} \mathrm{8.0]}$ and incubated at $30{ }^{\circ} \mathrm{C}$ for 7 days. Strain B2- $9^{\mathrm{T}}$ was isolated from a single colony, purified by repeated subcultivation and stored in middleorganic trypticase soy broth [containing $1^{-1}: 10 \mathrm{~g}$ trypticase soy broth (Difco)] supplemented with $15 \%$ glycerol $(\mathrm{v} / \mathrm{v})$ at $-80{ }^{\circ} \mathrm{C}$.

All tests were performed in parallel on strain B2- $9^{\mathrm{T}}$ and $H$. effusa DSM $16095^{\mathrm{T}}$. Growth was tested on trypticase soy agar (TSA; Difco), low-organic TSA [containing $\mathrm{l}^{-1}: 3 \mathrm{~g}$ trypticase soy broth and $15 \mathrm{~g}$ agar], nutrient agar (NA; laboratory prepared), Luria-Bertani agar (LB; Difco) and R2A agar (Difco). Strain B2-9 ${ }^{\mathrm{T}}$ grew well on low-organic TSA and R2A and weakly on TSA; however, the viability of cells declined rapidly when growing on TSA. Unlike $H$. effusa DSM $16095^{\mathrm{T}}$, strain B2-9 ${ }^{\mathrm{T}}$ could not grow on LB and NA agar, did not form diffuse colonies on minimal agar and formed cell aggregates in R2A broth.

Routine cultivation was conducted at $25{ }^{\circ} \mathrm{C}$ with $\mathrm{R} 2 \mathrm{~A}$ medium. Cell morphology was observed using photomicroscopy (BH-2; Olympus). Flagellation was examined by transmission electron microscopy (JEM-1400; JEOL) after negative staining with $1 \%(\mathrm{w} / \mathrm{v})$ phosphotungstic acid. Motility was observed using phase-contrast microscopy 
(CH30; Olympus). Gram reaction was determined according to Gerhardt et al. (1994). Catalase and oxidase activities, hydrolysis of casein, gelatin, aesculin, L-tyrosine, starch and Tweens 20, 40, 60 and 80 were determined as described by Dong \& Cai (2001). $\mathrm{H}_{2} \mathrm{~S}$ production was determined according to Bruns et al. (2001). Growth under anaerobic conditions was determined by incubation in an anaerobic chamber with anaerobically prepared R2A broth. Conditions for growth were tested in R2A broth with 0 $5.0 \%(\mathrm{w} / \mathrm{v}) \mathrm{NaCl}$ (at intervals of $0.5 \%$ ), at pH 5.0-10.5 (at intervals of $0.5 \mathrm{pH}$ unit) and at 5-35 (at intervals of $5^{\circ} \mathrm{C}$ ), 37 and $40{ }^{\circ} \mathrm{C}$. Generation time at $25{ }^{\circ} \mathrm{C}$ was determined in R2A broth and calculated from the change in optical density during the exponential growth phase. Growth on n-alkanes $\left(\mathrm{C}_{6}-\mathrm{C}_{19}\right)$ was performed according to Palleroni et al. (2004). Carbon source assimilation was determined according to Stanier et al. (1966). Additional biochemical properties and enzyme activities were determined using the API 20 NE and API ZYM systems (bioMérieux), according to the manufacturer's instructions. Susceptibility to antibiotics was determined using filter-paper discs (Beijing Pharmaceutical Company).

Cells of strain $\mathrm{B} 2-9^{\mathrm{T}}$ were Gram-negative, non-sporeforming rods $(0.7-0.8 \mu \mathrm{m}$ wide and $1.0-1.5 \mu \mathrm{m}$ long). Growth occurred by binary fission. Cells were motile by means of a single polar flagellum (Supplementary Fig. S1a, b, available in IJSEM Online). After growth on R2A agar for 3 days, cells of strain B2- $9^{\mathrm{T}}$ were covered with many vesicles and these vesicles were also seen free in the culture fluid (Supplementary Fig. S1b, c). No vesicles were observed for H. effusa DSM $16095^{\mathrm{T}}$ under the same culture conditions (Supplementary Fig. S1d). High magnification revealed that the vesicles were formed by local extensions of the peripheral wall layers without involvement of the cytoplasmic membrane, which suggests a possible mechanism of vesicle formation (Forsberg et al., 1981).

After 2 days at $30{ }^{\circ} \mathrm{C}$ on R2A agar, colonies of strain B2- $9^{\mathrm{T}}$ were transparent, non-pigmented, smooth, circular, convex and $1-2 \mathrm{~mm}$ in diameter. Growth occurred at $10-37{ }^{\circ} \mathrm{C}$ (optimum $20-25^{\circ} \mathrm{C}$ ) and $\mathrm{pH}$ 5.5-9.5 (optimum $\mathrm{pH}$ 7.0). $\mathrm{NaCl}$ was not required for growth but up to $1.0 \%(\mathrm{w} / \mathrm{v})$ $\mathrm{NaCl}$ was tolerated. In comparison with $H$. effusa DSM $16095^{\mathrm{T}}$, strain $\mathrm{B} 2-9^{\mathrm{T}}$ exhibited a higher maximum temperature and a lower maximum $\mathrm{NaCl}$ concentration for growth and a longer generation time (Table 1). Strain B2- $-9^{\mathrm{T}}$ grew well on $\mathrm{C}_{9}-\mathrm{C}_{17}$ and weakly on $\mathrm{C}_{6}-\mathrm{C}_{8}, \mathrm{C}_{18}$ and $\mathrm{C}_{19}$, while $H$. effusa DSM $16095^{\mathrm{T}}$ grew very well on all of the alkanes tested. The morphological, physiological and biochemical properties that differentiate strain $\mathrm{B} 2-9^{\mathrm{T}}$ from H. effusa DSM $16095^{\mathrm{T}}$ are given in Table 1 and additional characteristics of strain $\mathrm{B} 2-9^{\mathrm{T}}$ are given in the species description.

Table 1. Differential properties of strain B2-9 ${ }^{\top}$ and $H$. effusa DSM $16095^{\top}$

Strains: 1, Hydrocarboniphaga daqingensis sp. nov. B2-9 ${ }^{\mathrm{T}}$; 2, H. effusa DSM $16095^{\mathrm{T}}$. All data were taken from this study. R, Resistant; s, sensitive; + , positive; w, weakly positive; -, negative.

\begin{tabular}{|c|c|c|}
\hline Characteristic & 1 & 2 \\
\hline \multicolumn{3}{|l|}{ Colony/cell morphology } \\
\hline Diffuse colonies on minimal agar & - & + \\
\hline Vesicle-covered cells & + & - \\
\hline \multicolumn{3}{|l|}{ Cell dimensions $(\mu \mathrm{m})$} \\
\hline Width & $0.7-0.8$ & $0.75-0.85$ \\
\hline \multicolumn{3}{|l|}{ Growth on/at: } \\
\hline LB, NA & - & + \\
\hline $37^{\circ} \mathrm{C}$ & + & - \\
\hline Maximum $\mathrm{NaCl}$ concentration $(\%, \mathrm{w} / \mathrm{v})$ & 1.0 & 2.5 \\
\hline Generation time in $\mathrm{R} 2 \mathrm{~A}$ at $25{ }^{\circ} \mathrm{C}(\mathrm{h})$ & 1.5 & 2.3 \\
\hline \multicolumn{3}{|l|}{ Utilization of: } \\
\hline \multicolumn{3}{|l|}{ API ZYM } \\
\hline Esterase (C4) & + & - \\
\hline Cystine arylamidase, $\alpha$-glucosidase & $\mathrm{W}$ & - \\
\hline Lipase (C14) & - & + \\
\hline \multicolumn{3}{|l|}{ Antibiotic susceptibility ( $\mu$ g per disc): } \\
\hline Ampicillin (10), cefazolin (30), erythromycin (15), gentamicin (10) & s & $\mathrm{R}$ \\
\hline Clarithromycin (15) & $\mathrm{R}$ & S \\
\hline DNA G + C content $(\mathrm{mol} \%)$ & 66 & 61 \\
\hline
\end{tabular}


Genomic DNA extraction and sequencing of the 16S rRNA gene of strain $\mathrm{B} 2-9^{\mathrm{T}}$ were carried out according to the procedures by Kim et al. (1998). An almost-complete nucleotide sequence of the 16S rRNA gene (1487 nt) was obtained and compared with 16S rRNA gene sequences available in public databases using BLAST (Altschul et al., 1990; http://www.ncbi.nlm.nih.gov). A multiple alignment with closely related members was performed using CLUSTAL $\mathrm{x}$ (Thompson et al., 1994). Ambiguous and unalignable bases were manually omitted and phylogenetic trees were reconstructed using the neighbour-joining and maximumlikelihood algorithms available in MEGA (Kumar et al., 2004) and the maximum-parsimony algorithm available in PAUP (Swofford, 2002). Bootstrap analysis was performed according to the P-distance model. The phylogenetic analysis indicated that strain $\mathrm{B} 2-9^{\mathrm{T}}$ clustered with the genus Hydrocarboniphaga in the class Gammaproteobacteria ( $100 \%$ bootstrap support; Fig. 1). Strain B2-9 $9^{\mathrm{T}}$ exhibited $97.0 \% 16 \mathrm{~S}$ rRNA gene sequence similarity with $H$. effusa $\mathrm{AP} 103^{\mathrm{T}}$ and $<95.5 \% 16 \mathrm{~S}$ rRNA gene sequence similarity with its next closest phylogenetic neighbours, Nevskia soli GR15-1 ${ }^{\mathrm{T}}(95.1 \%)$, Nevskia ramosa Soe ${ }^{\mathrm{T}}(94.6 \%)$ and Alkanibacter difficilis MN154.3 $3^{\mathrm{T}}(93.4 \%)$.

For the analysis of cellular fatty acids, strain $\mathrm{B} 2-9^{\mathrm{T}}$ and $H$. effusa DSM $16095^{\mathrm{T}}$ were grown on low-organic TSA at $25{ }^{\circ} \mathrm{C}$ for 3 days, respectively. The fatty acids were determined using the MIDI Sherlock Microbial Identification System (Microbial ID), according to the manufacturer's instructions. Strain B2-9 $9^{\mathrm{T}}$ had a fatty acid profile similar to that of $H$. effusa DSM $16095^{\mathrm{T}}$ (Supplementary Table S1). The major fatty acids of strain $\mathrm{B} 2-9^{\mathrm{T}}$ were $\mathrm{C}_{18: 1} \omega 7 c(41.4 \%)$, summed feature 3 (iso$\mathrm{C}_{15: 0} 2-\mathrm{OH}$ and/or $\left.\mathrm{C}_{16: 1} \omega 7 c ; 18.5 \%\right)$ and $\mathrm{C}_{16: 0}(10.9 \%)$. Strain B2- $9^{\mathrm{T}}$ could be differentiated from $H$. effusa DSM $16095^{\mathrm{T}}$ by higher levels of $\mathrm{C}_{18: 1} \omega 7 c$ and $\mathrm{C}_{14: 0}$, lower levels of $\mathrm{C}_{16: 0}$ and $\mathrm{C}_{12: 0}$, presence of $\mathrm{C}_{15: 0}$ and absence of $\mathrm{C}_{14: 0}$ $2-\mathrm{OH}, \mathrm{C}_{16: 0} 2-\mathrm{OH}$ and iso- $\mathrm{C}_{17: 0} 3-\mathrm{OH}$.

The DNA $\mathrm{G}+\mathrm{C}$ content was determined by the thermal denaturation method (Marmur \& Doty, 1962). DNA from Escherichia coli $\mathrm{K}-12$ was used as a control. The DNA G + C content of strain $\mathrm{B} 2-9^{\mathrm{T}}$ was $66 \mathrm{~mol} \%$, which was a little higher than that of $H$. effusa DSM $16095^{\mathrm{T}}$ (61 mol\%).

Strain $B 2-9^{\mathrm{T}}$ shared several important characteristics with the genus Hydrocarboniphaga, such as being strictly aerobic, motile, oxidase- and catalase-positive, unable to reduce nitrate and, especially, able to utilize n-alkanes, which indicated that strain $\mathrm{B} 2-9^{\mathrm{T}}$ was a member of the genus Hydrocarboniphaga. However, several properties, including colony and cell morphology, growth on some media, temperature and $\mathrm{NaCl}$ concentration ranges for growth, carbon source utilization, enzyme activities, antibiotic susceptibility and DNA G+C content (Table 1), differentiated strain B2-9 $9^{\mathrm{T}}$ from H. effusa DSM $16095^{\mathrm{T}}$. To further distinguish strain B2- $9^{\mathrm{T}}$ from H. effusa DSM $16095^{\mathrm{T}}$, DNADNA hybridization was carried out using the thermal denaturation and renaturation method (De Ley et al., 1970) with modifications by Huß et al. (1983) and a DU 800 spectrophotometer (Beckman). DNA-DNA relatedness was determined on the basis of the liquid reassociation rate according to the formula given by De Ley et al. (1970):

$D \%=\frac{4 V_{m}-\left(V_{a}+V_{b}\right)}{2 \sqrt{V_{a}+V_{b}}} \times 100$

DNA-DNA relatedness between strain $\mathrm{B} 2-9^{\mathrm{T}}$ and H. effusa DSM $16095^{\mathrm{T}}$ was $24 \%$.

On the basis of phenotypic, genotypic and phylogenetic data, strain $\mathrm{B} 2-9^{\mathrm{T}}$ is considered to represent a novel species of the genus Hydrocarboniphaga, for which the name Hydrocarboniphaga daqingensis sp. nov. is proposed.

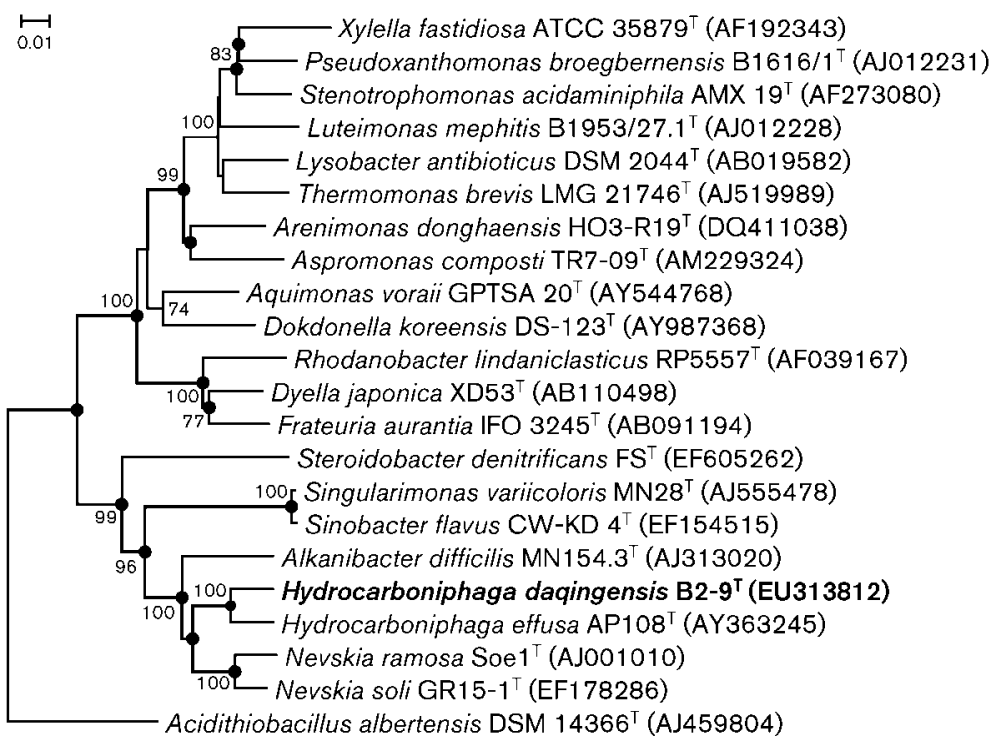

Fig. 1. Neighbour-joining tree based on $16 \mathrm{~S}$ rRNA gene sequences showing the phylogenetic positions of strain $B 2-9^{\top}$ and representatives of some other related taxa. Bootstrap values $(>70 \%)$ based on 1000 replications are shown at branch nodes. Filled circles indicate that the corresponding nodes were also recovered in maximum-likelihood and maximum-parsimony trees. Acidithiobacillus albertensis DSM $14366^{\top}$ was used as an outgroup. Bar, 0.01 substitutions per nucleotide position. 


\section{Description of Hydrocarboniphaga daqingensis sp. nov.}

Hydrocarboniphaga daqingensis (da.qin.gen'sis. N.L. fem. adj. daqingensis pertaining to Daqing, where the type strain was isolated).

Strictly aerobic and heterotrophic. Cells are Gram-negative, non-spore-forming rods $(0.7-0.8 \mu \mathrm{m}$ wide and $1.0-1.5 \mu \mathrm{m}$ long). Divides by binary fission. Motile by means of a single polar flagellum. After 2 days at $30{ }^{\circ} \mathrm{C}$ on R2A agar, colonies are transparent, non-pigmented, non-diffuse, smooth, circular, convex and $1-2 \mathrm{~mm}$ in diameter. Grows at $10-37{ }^{\circ} \mathrm{C}$ (optimum $20-25{ }^{\circ} \mathrm{C}$ ), at $\mathrm{pH} 5.5-9.5$ (optimum $\mathrm{pH} 7.0$ ) and with $\leqslant 1.0 \%(\mathrm{w} / \mathrm{v}) \mathrm{NaCl}$. Oxidaseand catalase-positive. Hydrolyses L-tyrosine and weakly hydrolyses aesculin, but does not hydrolyse casein, gelatin or starch. Negative for nitrate reduction, indole production, glucose fermentation and arginine dihydrolase, urease and $\beta$-galactosidase. Grows well on n-alkanes $\mathrm{C}_{9}-\mathrm{C}_{17}$ and weakly on $\mathrm{C}_{6}-\mathrm{C}_{8}, \mathrm{C}_{18}$ and $\mathrm{C}_{19}$. Utilizes L-isoleucine and Lleucine and weakly utilizes erythritol, but does not utilize isoamyl alcohol, L-arginine, L-glutamate, L-phenylalanine, lactic acid, $p$-aminobenzoic acid, benzoic acid, creatine, Dcalcium pantothenate, asparagine, L-histidine, L-ornithine, L-serine or fumaric acid. With API ZYM, positive for alkaline phosphatase, esterase (C4), esterase lipase (C8), leucine arylamidase, valine arylamidase, trypsin and naphthol-AS-BI-phosphohydrolase and weakly positive for cystine arylamidase, acid phosphatase and $\alpha$-glucosidase. Sensitive to ( $\mu \mathrm{g}$ per disc unless otherwise stated) ampicillin (10), carbenicillin (100), cefazolin (30), chloramphenicol (30), ciprofloxacin (5), erythromycin (15), gentamicin (10), kanamycin (30), norfloxacin (10), novobiocin (5), penicillin (10 U), rifampicin (5), tetracycline (30) and vancomycin (30); resistant to cefradine (30), clarithromycin (15), oxacillin (1) and polymyxin B $(300 \mathrm{U})$. The major fatty acids are $\mathrm{C}_{18: 1} \omega 7 c$, summed feature $3\left(\mathrm{C}_{16: 1} \omega 7 c\right.$ and/or iso- $\left.\mathrm{C}_{15: 0} 2-\mathrm{OH}\right)$ and $\mathrm{C}_{16: 0}$. The DNA $\mathrm{G}+\mathrm{C}$ content of the type strain is $66 \mathrm{~mol} \%$.

The type strain, B2-9 $9^{\mathrm{T}} \quad$ =CGMCC $1.7049^{\mathrm{T}}=\mathrm{NBRC}$ $104238^{\mathrm{T}}$ ), was isolated from water of Longhu Lake, Daqing, north-east China.

\section{Acknowledgements}

This work was supported by grants from the Ministry of Science and Technology of China (863 Program; grant number 2006AA06Z316) and the Knowledge Innovation Program of the Chinese Academy of Sciences (grant number KSCS2-YW-G-055-01).

\section{References}

Altschul, S. F., Gish, W., Miller, W., Myers, E. W. \& Lipman, D. J. (1990). Basic local alignment search tool. J Mol Biol 215, 403410.

Bruns, A., Rohde, M. \& Berthe-Corti, L. (2001). Muricauda ruestringensis gen. nov., sp. nov., a facultatively anaerobic, appendaged bacterium from German North Sea intertidal sediment. Int $J$ Syst Evol Microbiol 51, 1997-2006.

De Ley, J., Cattoir, H. \& Reynaerts, A. (1970). The quantitative measurement of DNA hybridization from renaturation rates. Eur $J$ Biochem 12, 133-142.

Dong, X.-Z. \& Cai, M.-Y. (2001). Determinative Manual for Routine Bacteriology. Beijing: Scientific Press (English translation).

Forsberg, C. W., Beveridge, T. J. \& Hellstrom, A. (1981). Cellulase and xylanase release from Bacteroides succinogenes and its importance in the rumen environment. Appl Environ Microbiol 42, 886-896.

Gerhardt, P., Murray, R. G. E., Wood, W. A. \& Krieg, N. R. (1994). Methods for General and Molecular Bacteriology. Washington, DC: American Society for Microbiology.

Huß, V. A. R., Festl, H. \& Schleifer, K. H. (1983). Studies on the spectrophotometric determination of DNA hybridization from renaturation rates. Syst Appl Microbiol 4, 184-192.

Kim, S. B., Falconer, C., Williams, E. \& Goodfellow, M. (1998). Streptomyces thermocarboxydovorans sp. nov. and Streptomyces thermocarboxydus sp. nov., two moderately thermophilic carboxydotrophic species from soil. Int J Syst Bacteriol 48, 59-68.

Kumar, S., Tamura, K. \& Nei, M. (2004). MEGA3: integrated software for molecular evolutionary genetics analysis and sequence alignment. Brief Bioinform 5, 150-163.

Marmur, J. \& Doty, P. (1962). Determination of the base composition of deoxyribonucleic acid from its thermal denaturation temperature. J Mol Biol 5, 109-118.

Palleroni, N. J., Port, A. M., Chang, H.-K. \& Zylstra, G. J. (2004). Hydrocarboniphaga effusa gen. nov., sp. nov., a novel member of the $\gamma$-Proteobacteria active in alkane and aromatic hydrocarbon degradation. Int J Syst Evol Microbiol 54, 1203-1207.

Stanier, R. Y., Palleroni, N. J. \& Doudoroff, M. (1966). The aerobic pseudomonads: a taxonomic study. J Gen Microbiol 43, 159-271.

Swofford, D. L. (2002). PAUP*: phylogenetic analysis using parsimony (and other methods), version 4. Sunderland, MA: Sinauer Associates.

Thompson, J. D., Higgins, D. G. \& Gibson, T. J. (1994). CLUSTAL W: improving the sensitivity of progressive multiple sequence alignment through sequence weighting, position-specific gap penalties and weight matrix choice. Nucleic Acids Res 22, 4673-4680. 